ler als kleinere, so dass z. B. bei einem Chromatogramm von $D-, L$ - und $D L-$ Histidin je nach den I'mständen bei Besprühen mit Pauly-Reagenz zu (nrecht der Eindruck einer Trennung in die Intipoden entstehen kamn. . Iuf diese Weise kam man beliebige Effekte crziclen. Für das Chromatogramm in Figur 2 wurden die Mengen so gewählt, dass eine Terteilung von Rf-lYerten zustandekam, wie sie in keinem lall bei einer Trennung in . Intipoden $z u$ erwarten ist. Im schnclisten kufen hior $30 y$ $D L$-Histidin, dann folgen $20 \% D$ - und $15, L$-llistidin. "Gewichtsloser" Tracer allein bleibt am weitesten zurück. Auf einer anderen Papiersorte, Whatman Nr. 4 , die diesen Konzentrationseffekt nicht zeigt, erfolgt diagegen mit Sicherheit cine Antipodentrennung (ligur 3). Ein cinwandfreier Nachweis der tatsächlichen Vorgänge wirl also besonders für eine gleichzeitige und unabhängige Identifizierung von optischen Intipoden (als Substanzen

\section{New Centrally Acting Drugs: Coumarin Derivatives}

According to JONGEBREUR ${ }^{1}$, there seems to be no pharmacological difference in coronary-dilator potency between chromone and coumarin derivatives. Is a number of N-substituted 8 -amino-methyl-7-methoxy and 7-hydroxychromones and flavones with central nervous system (C.N.S.) stimulating activity have recently been described ${ }^{2,3}$, we thought it interesting to test whether this activity was retained in the corresponding coumarin derivatives. These are represented by the general formula :

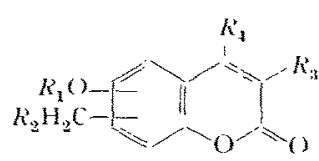

$$
\begin{aligned}
& k_{1}-\mathrm{H}_{4} \mathrm{CH}_{3} \\
& K_{2}=\mathrm{X}\left(\mathrm{CH}_{3}\right)_{2},-\mathrm{N}_{2}\left(\mathrm{C}_{2} \mathrm{H}_{5}\right)_{2} \\
& x^{-}, 0 \\
& K_{3}=\mathrm{H}_{4}, \overline{\mathrm{H}}_{3}, \mathrm{C}_{2} \mathrm{H}_{5}, \mathrm{C}_{4} \mathrm{H}_{5} \\
& k_{1}-\mathrm{H}, \mathrm{CH}_{3}, \mathrm{C}_{2} \mathrm{H}_{5}
\end{aligned}
$$

in which the positions of the hydroxy or methexy group and the basic chain were $7,8-7,6-6,5$ - and 8,5 respectively. These compounds were prepared via the Mannich reaction on hydroxycoumarins or by means of the chloromethylation procedure applied to methoxy analogues, followed by amination. In both cases, secondary amines such as dimethyl and diethylamine, piperidine and morpholine were employed.

The pharmacological screening of fifty coumarin derivatives has shown that the C.N.S. stimulating activity is retained, though to a lower degree than in the corresponding chromone and flavone compounds. No difference is noticeable between hydroxy and methoxy derivatives, although the latter seem to furnish the most active compounds. The optimal position for the methoxy group and the basic chain is the ortho position, and, of the locations ghloicher skalarer crössen "roeben diese ähnliche l'robleme wie lentersuchungen aber Selbstelifusion) nur chuch die Simultanaultagme rationktiver Tracer ermörlicht.

Simmang. Weightless amonnts of rahnactive testmixture's are run from the same starting point ats the compounds to inrestigate while checked independently. It is shown that this allows a dependable identification even in cases where the technipue of inative parallel rumbing testmixtures fails completely.

F. VISTER und W. REMTR

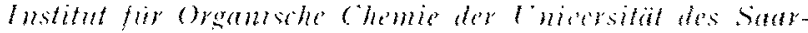

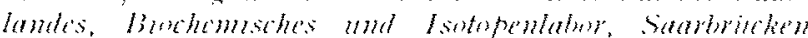

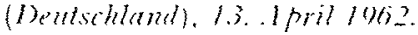

tried, the 6:5 pesitions were found to be the best for C.X.S. stimulating activity. When the oxygen function and the basic chan are para to one another, a comsiderable loss of activity is abserved, $a^{2}$. in the $N$-substituted 5 aminomedhy-8nethoxy (and s-hylroxy) derivatives, with the sole exception of $3-$ methy-k-methey- $-5-d i-$ mehylaminomethrlcumarin.

of the basic chams, the dimethyaminumethyl is the most efficint, ats th the corresponding chromene and

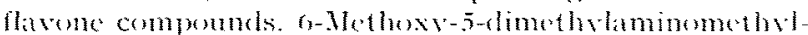
3-phenylesumarin (Rec $1+-607.3$ ) seems to be the most active componol in the series. Its activity expressed as the reciprocal of the intraperitoneal L, se $_{\text {of }}$ me'trazel (71 $\mathrm{mg} / \mathrm{kg}$ ) was $17 \mathrm{~s}$, on a molar basis, i.e. half that of the most active eompound in the chromone series.

Righsmats. Si descrive ma nueva classe di famaci stimelanti il sistema nerveses contrale, rappresentata dalle aminometihdrossi- e dalle aminometrmetessicumarine X-sostituite.

L'attivita di questi nuovi compesti e inferiore a quella dei corrispondenti isomeri derivati dal cromone the dal nirvone.

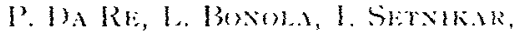
and M. J. Maristerth

beparthent of Medical Chemistry and beparmint of Pharmacology, Research Ditision, Recordati Sip.t., Milano (Italy), June 1,10$) 2$.

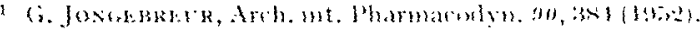

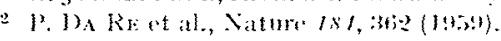

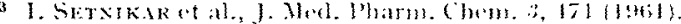

